\title{
Effects of ensiling on the quality of protein supplements for honey bees Apis mellifera
}

\author{
Juliana Pereira Lisboa Mohallem PAIvA ${ }^{1}$, Elisa Esposito ${ }^{1}$, \\ Gabriel Inácio de Morais Honorato De SouzA ${ }^{1}$, Tiago Mauricio Francoy ${ }^{2}$, \\ Michelle Manfrini Morais ${ }^{3}$ \\ ${ }^{1}$ Instituto de Ciência e Tecnologia, Universidade Federal de São Paulo, São José dos Campos, São Paulo 12231-280, \\ Brazil \\ ${ }^{2}$ Escola de Artes, Ciências e Humanidades, Universidade de São Paulo, São Paulo, São Paulo 03828-000, Brazil \\ ${ }^{3}$ Departamento de Ecologia e Evolução, Universidade Federal de São Paulo, Diadema, São Paulo 09920-000, Brazil
}

Received 10 July 2018 - Revised 19 April 2019 - Accepted 3 June 2019

\begin{abstract}
We developed a nutritious, palatable, and attractive fermented diet as supplementary food for honey bees (Apis mellifera ) during periods of natural food scarcity. Two types of commercial silage inoculants were tested; bacteria and a mix of bacteria and fungi were used to ferment a protein-based feed for 7, 14, or 28 days. The positive control consisted of beebread and the negative controls were sucrose solution $50 \%, w / v)$ and the unfermented protein diet. These feeds were offered, $4 \mathrm{~g}$ each, along with sucrose solution ad libitum, to 60 worker bees confined in plastic cages (seven replicates, 7 days). A pool of 20 bees/cage was collected on the first day (day 0 ) and on the 7 th day of the experiment, for protein quantification by the Bradford method and for the electrophoretic profile of the proteins by SDS-polyacrylamide gel electrophoresis. The diets fermented for 7 days were the most consumed when compared with unfermented protein diet and with beebread. All the bees that ate the fermented feeds (except for the 28-day fermentation period) presented higher titers of protein in the hemolymph when compared with the bees that did not consume any protein food (negative control and day 0 ). The electrophoretic analysis presented a protein profile compatible with good protein expression in the hemolymph of the bees that consumed the fermented feeds, in comparison with bees that had no access to a protein diet. Consequently, we conclude that fermenting protein supplements with silage inoculants is a viable alternative for producing protein diets that are nutritious and palatable for honey bees.
\end{abstract}

\section{Apis mellifera / fermentation / artificial diets / inoculants}

\section{INTRODUCTION}

Honey bee nutrition has become a subject of interest, due to its importance for colony development and productivity (Wright et al. 2017). Bees collect nectar and pollen from flowers. Through enzymatic reactions, they transform sugar and proteins from the collected food into honey and

Corresponding author: J. Paiva, jplbiologia@gmail.com

Manuscript editor: James Nieh beebread (Somerville and Rural Industries Research and Development Corporation (Australia) 2005; Nicolson 2011; Anderson et al. 2013; Urcan et al. 2018). Using these strategies, bees attempt to maintain a balanced diet, essential for good performance and health (Winston 2003; Brodschneider and Crailsheim 2010; Morais et al. 2013a). Among the collected resources, pollen is the main source of proteins and lipids. It is needed for brood rearing and for the satisfactory development of adult bees (Crailsheim 1990; Roulston and Cane 2000; Hoover et al. 2006). During times of pollen dearth, pollen reserves in the combs and protein reserves in bees are rapidly 
expended (Morais et al. 2013b; Paiva et al. 2016). Consequently, artificial supplementation with protein diets has been of extreme importance for colony maintenance and development (Morais et al. 2013a) and for maintaining colony strength for pollination services and honey production (Herbert Jr, 1992). If there is no pollen, or a good pollen substitute is not available to the colonies, brood production can diminish or even stop completely (Haydak 1963). Pollen collected from honey bee colonies could be used in times of food shortage; however, this is expensive and incurs the risk of spreading pathogens (De Jong et al. 2009; Brodschneider and Crailsheim 2010). Provision of artificial diets is a safe way to feed bees protein (Paiva et al. 2016). However, many nutritional supplements are poorly accepted by bees and have low nutritional value (Schmidt and Hanna 2006). Adequate diet formulation, deterioration during storage, attractiveness to bees, and diet costs are major concerns (Herbert. and Shimanuki 1977). To develop artificial protein diets that are nutritious and attractive to bees, it would make sense to produce them as similar as possible to their natural food in the hive, beebread (Almeida-Dias et al. 2018). Beebread is a fermented food, mainly due to the action of bacteria (like the genus Lactobacillus), making fermented pollen richer in nutrients and improving its preservation (Anderson et al. 2013). The Lactobacillus group includes important fermenting organisms, some of which are used in silage production. Loper et al. (1980), Vasques and Olofsson (2009), Anderson et al. (2015), and Anderson and Ricigliano (2017) found these Lactobacillus spp. in the digestive system and in beebread of honey bees, justifying the choice of these organisms. DeGrandi-Hoffman et al. (2012) found that there is an increase in the concentration of amino acids in the beebread when compared with unfermented pollen, which makes it more nutritious, since the microorganisms secrete enzymes that act on the cellular wall of pollen grains, releasing their contents for digestion.

The use of microorganisms isolated from beebread for the fermentation of feed for bees has been shown to be effective in the production of food more acceptable to these insects (AlmeidaDias et al. 2018). However, such inocula are very variable and difficult to standardize, because there are nutritional and microbiological variations in beebread, according to the plant species from which the pollen was collected, as well as locality and time of year; in the spring, beebread is nutritionally richer when compared with autumn (DeGrandi-Hoffman et al. 2018). The use of standardized microbial strains, especially those obtained from commercial inoculants for silage, would allow greater control of the fermentation process, facilitating the process of obtaining these fermented foods, especially if the goal is largescale fermented feed production for bees. Another advantage in the use of commercial inoculant strains is the production of these foods in a safer way. The objective of this study is to produce a fermented diet similar to the natural one, with greater preservation of nutrients, more palatable and attractive for the animals.

Taking these factors into consideration, we tested whether fermentation with silage microorganisms would enhance consumption and utility of a pollen substitute diet.

\section{METHODS}

\subsection{Preparation of the fermented diet}

The unfermented diet (fresh) used in this work was developed by mixing the protein ingredients shown in Table I. Two supplementary fermented protein diets were produced on the same ingredient basis. The differences were the microbial inoculants used to ferment them: Fermented Diet K, inoculant Kerasil ${ }^{\circledR}$, only bacteria (produced by Kera Brasil@); Fermented Diet KS (inoculant Supersile $\AA$, a mix of bacteria and fungi, produced by Strong Microbials ( ). Each feed batch was composed of $100 \mathrm{~g}$ of the ingredients, $40 \mathrm{~mL}$ of autoclaved sucrose solution (prepared with distilled water and 50\% $(w / v)$ refined sucrose) and lyophilized silage inoculant, mixing with a sterile glass rod until the formation of a doughy mass. After mixing the ingredients, they were transferred to separate glass jars and maintained at $37{ }^{\circ} \mathrm{C}$ in bacteriological incubators for fermentation for different periods of time $(7,14$, or 28 days) (Figure 1). 
Table I. Ingredients, crude protein levels (\%) and commercial inoculants used in each diet (treatment)

\begin{tabular}{|c|c|c|c|c|c|c|c|}
\hline Treatment & $\begin{array}{l}\text { Powdered } \\
\text { eggs (g) }\end{array}$ & $\begin{array}{l}\text { Soy } \\
\text { meal } \\
(\mathrm{g})\end{array}$ & $\begin{array}{l}\text { Sugar cane } \\
\text { yeast }(\mathrm{g})\end{array}$ & $\begin{array}{l}\text { Ground } \\
\text { hominy } \\
\text { (g) }\end{array}$ & $\begin{array}{l}\text { Sucrose } \\
(\mathrm{g})\end{array}$ & $\begin{array}{l}\% \text { Crude } \\
\text { protein }\end{array}$ & Inoculant \\
\hline $\begin{array}{c}\text { Unfermented } \\
\text { diet (fresh) }\end{array}$ & 5 & 20 & 35 & 15 & 24 & 29.1 & - \\
\hline K7 & 5 & 20 & 35 & 15 & 24 & 17.3 & Kerasil ${ }^{\circledR} 0.5 \mathrm{mg}$ \\
\hline K14 & 5 & 20 & 35 & 15 & 24 & 21.8 & Kerasil® $0.5 \mathrm{mg}$ \\
\hline K28 & 5 & 20 & 35 & 15 & 24 & 24.2 & Kerasil ${ }^{\circledR} 0.5 \mathrm{mg}$ \\
\hline KS7 & 5 & 20 & 35 & 15 & 24 & 21.4 & $\begin{array}{l}\text { Kerasil } ₫ 0.5 \mathrm{mg}+ \\
\text { Supersile } ₫ 0.3 \mathrm{mg}\end{array}$ \\
\hline KS14 & 5 & 20 & 35 & 15 & 24 & 21.4 & $\begin{array}{l}\text { Kerasil@ } 0.5 \mathrm{mg}+ \\
\text { Supersile® } 0.3 \mathrm{mg}\end{array}$ \\
\hline KS28 & 5 & 20 & 35 & 15 & 24 & 20.2 & $\begin{array}{l}\text { Kerasil } ₫ 0.5 \mathrm{mg}+ \\
\text { Supersile } ₫ 0.3 \mathrm{mg}\end{array}$ \\
\hline $\mathrm{C}+$ & - & - & - & - & - & 26.7 & - \\
\hline
\end{tabular}

Inoculants: Kerasil: bacteria (Lactobacillus and Pediococcus); Supersile: bacteria (Lactobacillus sp., Bacillus sp., Enterococcus faecium, Pediococcus acidilacti), fungi (Aspergillus niger and Trichoderma longibrachiatrum ). The amount of inoculant added is based on the manufacturer's recommendations; $100 \mathrm{~g}$ of inoculant is sufficient to ferment up to 50 tons of silage.

\subsection{Caged bees and determination of the consumption rate for each diet}

Bee cages containing 60 newly emerged Africanized honey bees were prepared according to Morais et al. (2013b), collected from four different Africanized honey bee colonies (from APTA, Pindamonhangaba, SP) were mixed and placed into hoarding cages maintained in an incubator, with feeders containing the protein diet (in paste form) and vials containing 50\% $\mathrm{w} / \mathrm{v}$ sucrose syrup. Seven cages were prepared for each treatment with the following diets: protein diet that had been fermented with silage bacteria for 7,14 , or 28 days; protein diet that had been fermented with silage bacteria + fungi for 7, 14, or 28 days; beebread; unfermented protein diet (fresh); zero protein diet consisting of sucrose syrup 50\% $\mathrm{w} / \mathrm{v}$ ad libitum.

Each cage of each experiment was initially provided with $2 \mathrm{~g}$ of diet. The food was changed on the fourth day of the experiment, in order to avoid problems with drying out and contamination. Feed consumption was measured by weighing the leftovers in the feeders. The bees in the cages were maintained in an incubator in the dark at $34{ }^{\circ} \mathrm{C}$ and $80 \%$ relative humidity.

The total amount of consumed protein was calculated by multiplying the consumption of each diet by the percentage of crude protein in the respective diet.

\subsection{Quantification of hemolymph protein and measurements of vitellogenin and hexamerin levels}

Protein levels in the hemolymph of the day 0 bees and caged bees after 7 days and consumption were measured. Workers (20) were randomly collected from each cage and hemolymph was collected with a pipette from a small incision made with entomological scissors at the base of the bees' wings. The total protein in the hemolymph was determined by spectrophotometry, at $595 \mathrm{~nm}$, measured according to the methodology given by Cremonez et al. (1998) and Bradford (1976) method.

Hemolymph collected from the workers (pool of 20 bees/cage) was submitted to SDSpolyacrylamide gel electrophoresis, using sodium dodecyl sulfate (SDS)-polyacrylamide (7.5\%) 


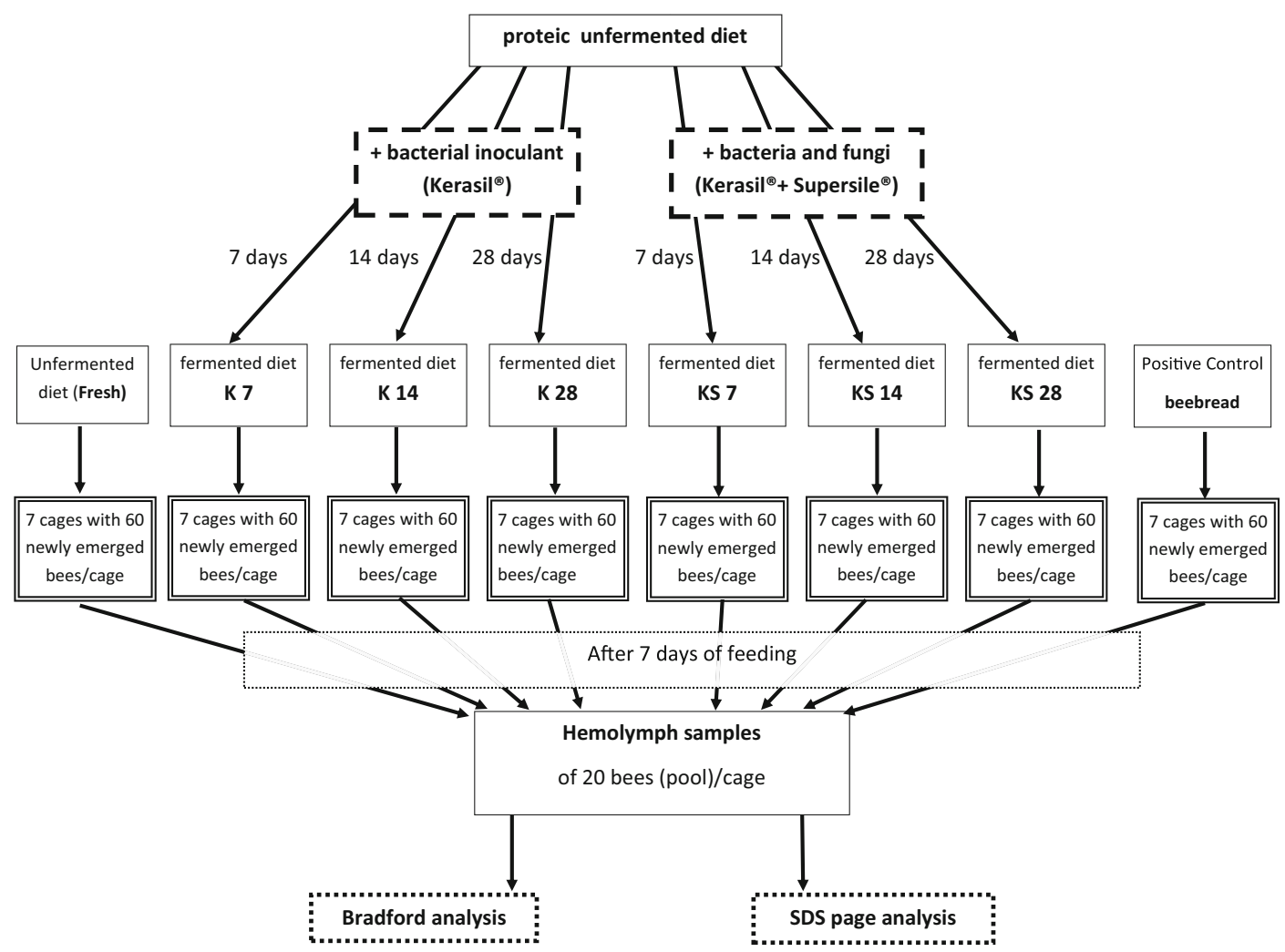

Figure 1 Flowchart detailing the stages of the experiment with the fermented diets.

gels, subsequently stained with Coomassie Brilliant Blue. Protein was quantified according to the methodology proposed by Hu and Beeton (2010). Analysis of the electrophoretic profile of proteins (Vg and Hex) indicates the nutritional status of the animals. The numerical values, in arbitrary units (AU), extracted from the gel bands are determined from the color scale analysis of the protein bands in the acrylamide gels, using image analysis in Image $\mathrm{J}$ software; the darker the band, the more protein it contains, converted to numerical values in the form of AU.

\subsection{Statistical analysis}

Consumption rates and protein titers in the hemolymph were compared through ANOVA on ranks, (Tukey's test for pair-wise comparisons), using SigmaStat $\odot 3.5$ (Statsoft 2007), using $\alpha=$ 0.05 and $P<0.05$. Data from the Bradford quantification of diet proteins were compared using one-way ANOVA, with a confidence level of $95 \%$. Multiple pair-wise comparisons were performed according to the Holm-Sidak method. We also ran a Pearson correlation analysis between the total amount of crude protein in the different diets and the consumption rates.

\section{RESULTS}

\subsection{Determination of the consumption rate for each diet}

Overall, the consumption of fermented diets was superior in comparison with the unfermented control $(\mathrm{F})(P<0.05)$, except for $\mathrm{K} 14$ and K28, which were not significantly different from the control (Figure 2). We also found that consumption of beebread $(\mathrm{C}+$, Figure 2) was the lowest among all protein diets. Consumption was significantly and negatively correlated with the 


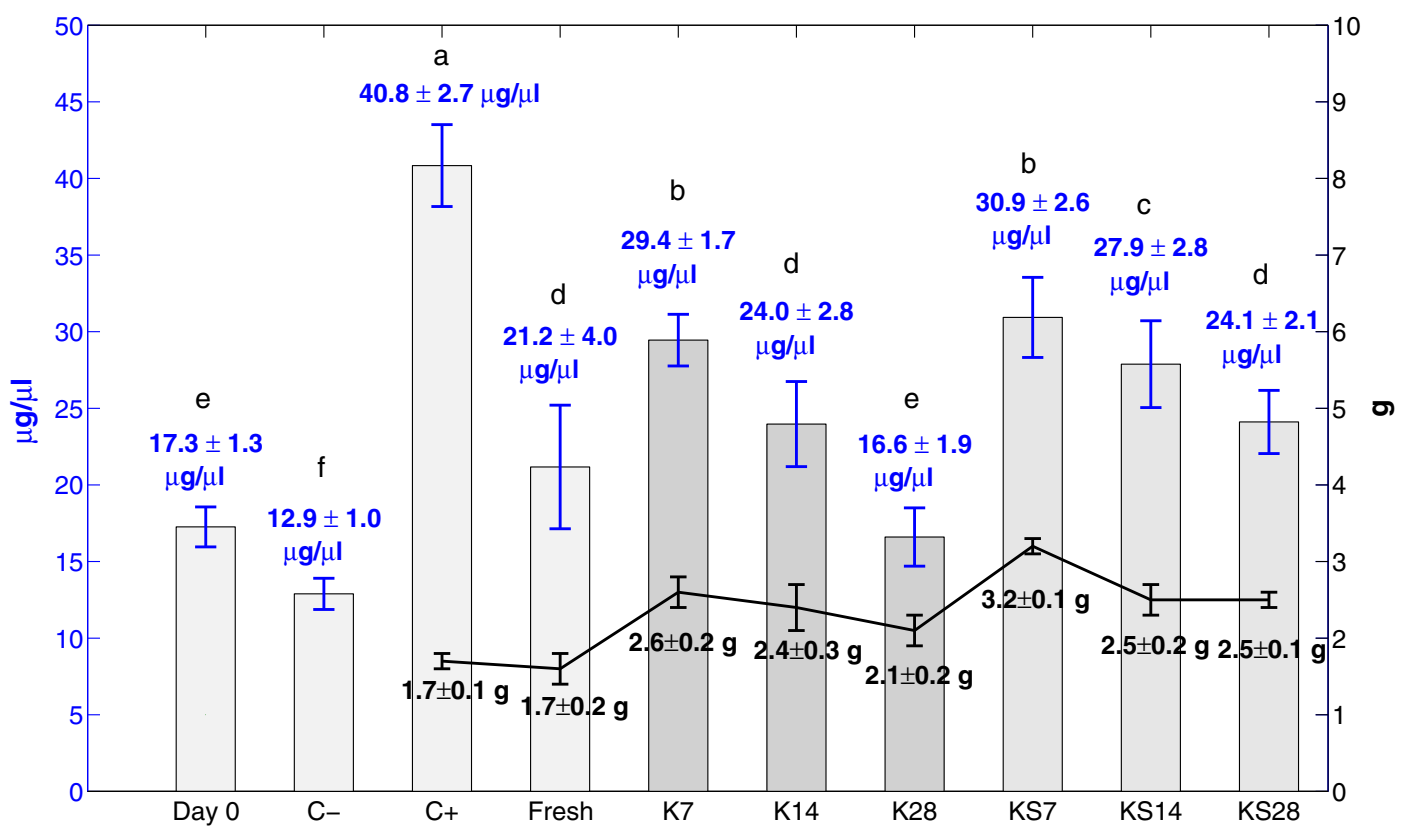

Figure 2 Protein titers in caged bee hemolymph (bars) and diet consumption (line). Different letters indicate statistical differences: fermented diets, fresh, day 0 , and $\mathrm{C}-$ versus control $(\mathrm{C}+) . \alpha=0.05, P<0.05$.

percentage of crude protein in the diets $(R=$ $-0.79 ; P=0.02)$.

\subsection{Quantification of hemolymph protein and vitellogenin and hexamerin levels}

The mean levels of protein in the hemolymph of workers in cages fed with protein diets $\mathrm{C}+, \mathrm{K} 7$, $\mathrm{KS} 7$, and KS14 were significantly higher than in those fed with sucrose syrup alone. Bees fed with beebread, K7, and KS7 performed better than bees fed with unfermented protein diet $(P<0.05)$ (Figure 2). No significant differences were found when comparing bees fed with unfermented protein diet versus the other fermented diets. Also, no significant differences were found when comparing bees fed with beebread, K7, and KS7, indicating the superiority of these diets, in comparison with the others. For the group represented by day 0 (freshly emerged bees, which had not yet consumed any food), in the protein titers in the hemolymph, we observed a significant difference $(P<0.0001)$ between this group and the groups positive control $(\mathrm{C}+), \mathrm{K} 7$, and $\mathrm{KS} 7$.
We found that the K7 and KS7 diets were superior to an unfermented protein diet and had a performance similar to that of beebread.

Analyzing the expression of the $\mathrm{Vg}$ protein using the one-way ANOVA test, with $\alpha=0.05$, we observed that the unfermented protein treatment (fresh) was significantly inferior to the groups positive control beebread (C+), K7, KS7, and KS14. When we compared the unfermented protein diet with the other treatments (K14, K28, and KS28), we did not observe a significant difference. All protein dietary treatments were significantly superior to day zero (D0) and negative control (C-) (Figure 3 ). We have also observed a significant difference between the negative control $(\mathrm{C}-)$ and treatments $\mathrm{K} 7(P=0.05), \mathrm{KS} 7(P<$ $0.02)$, and $\mathrm{KS} 14(P=0.04)$. Comparing the unfermented diet $(F)$ with the other diets, we did not observe a significant difference between treatments.

When we examined the expression of Hex, only the KS28 treatment was significantly inferior to the treatments $\mathrm{K} 7$ and $\mathrm{KS} 7(P<0.05)$. No significant differences were observed between the other treatments composed of the 

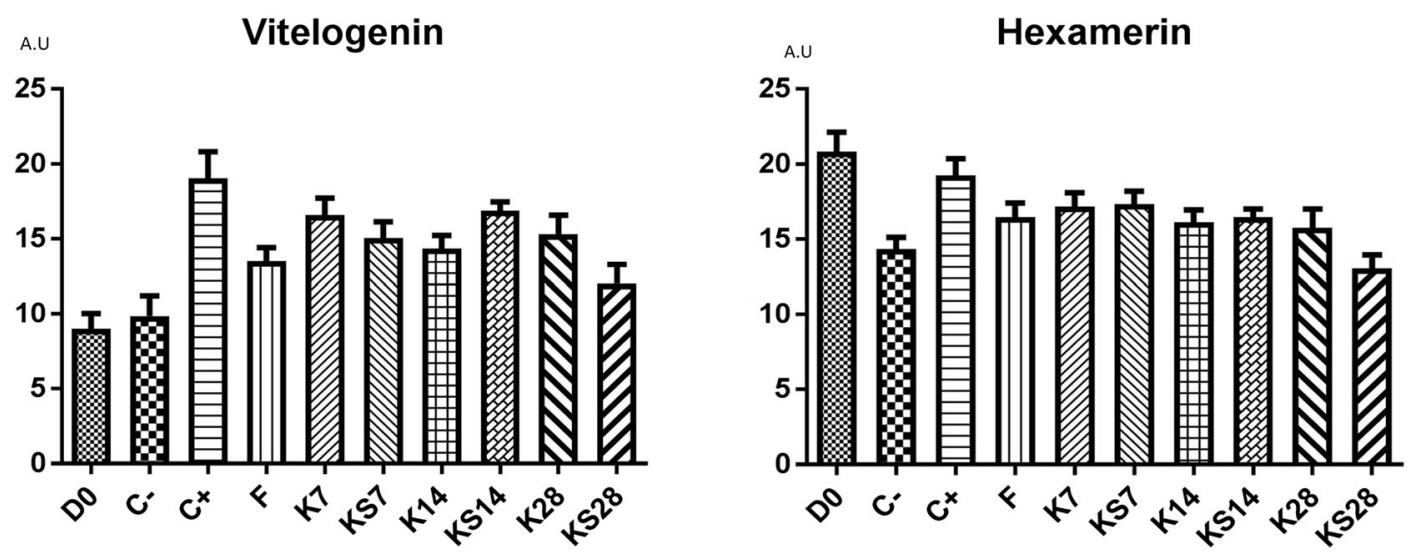

Figure 3 Protein expression of vitellogenin and hexamerin after feeding the different diets in arbitrary units (AU).

fermented diets and between these and the control. We observed a tendency of group D0 to present higher values than the other groups (Figure 3). In this case, bees fed with these two diets also presented patterns of $\mathrm{Vg}$ and Hex in the hemolymph similar to the patterns of the bees that were fed with beebread. Since these two proteins are good indicators of nutritional quality in bees, we can assume that the two diets were able to provide the major nutrients necessary to maintain workers that are healthy and have normal physiology.

\section{DISCUSSION}

The use of commercial lineages of microbes helps standardize the fermentation process and would be useful for production on a commercial scale. In our experiments, we achieved good results with the use of microorganisms from commercial inoculants for cattle silage, which standardizes the fermentation process, since the same strain was used in all the trials. Another option that uses microorganisms from beebread is highly variable in several aspects, including season, pollen species, and the possibility of disease transmission via the inoculum (Gilliam et al. 1990; Brindza et al. 2010). The importance of the ensilaged diet for bees consists in the fact that ensiling is based on the fermentation of a food, in which a predominance of bacteria producing lactic acid and acetic acid contribute to better conservation of the food and its constituent nutrients. As with green fodder stored in silos, the use of microorganisms from commercial inoculants is a viable option for the production of a fermented food for bees, since the technique improves the acceptance of food by the animals in a similar way to what occurs with beebread in the colony, as found by Ellis and Hayes Jr (2009), who demonstrated that bees prefer to consume fermented food.

Using lyophilized organisms avoids the need for preparation of an inoculum, a process that usually takes 10-14 days before diet fermentation, as proposed by Almeida-Dias et al. (2018). However, one of the most important advantages in our process is the reduction in time needed to ferment the diet, since the procedures described in the literature take from 17 to 28 days (Ellis and Hayes 2009; Almeida-Dias et al. 2018), while our diet is ready for use after only 7 days. Here, we used a similar process to the one used to ferment cattle feed. It involves the addition of microorganisms from specific silage additives, especially bacteria of the genera Lactobacillus, Pediococcus, and Bacillus and fungi of the genera Trichoderma and Aspergillus. These microorganisms, under anaerobic conditions, convert the sugar present in the original food to organic acids, mainly lactic acid (Aksu et al. 2004; Kristensen et al. 2010) and some enzymes (Peng et al. 2012). This helps to improve digestibility and increases the efficiency of the use of 
nutrients by the bees (Keady et al. 1994; Peng et al. 2012; Wright et al. 2017). Additionally, the lactic acid in the diets keeps the $\mathrm{pH}$ low, inhibiting the growth of decomposing organisms, especially those of the genus Clostridium (Venus et al. 1992; Schröder 2013). Finally, maintenance of the original nutrients in the fermented diet is vital to their storage so that the beekeeper can provide it to the bees in times of dearth (Kung and Ranjit 2001). The diets that were most consumed were the fermented diets. This is probably due to the superior palatability of the fermented diets, increasing their acceptance and consumption (Ellis and Hayes Jr, 2009). The addition of the microorganisms had a fundamental role in the production of a fermented diet, closer to the natural one, because besides improving palatability, which is a recurrent problem in the formulation of diets, fermentation improves digestibility, since the microorganisms release enzymes that perform a pre-digestion of nutrients, especially sugars, conserving food and inhibiting the growth of spoilage bacteria. Studies also point out the benefit of microorganisms as probiotics, especially the genus Lactobacillus (Alberoni et al. 2016). As stated before, pollen is the natural protein food for the bees and provides all the necessary nutrients for the natural development of the individuals. This may explain the low consumption of the positive control diet (beebread), since the high nutritional value of the pollen allows the bees to meet their nutritional necessities with smaller amounts when compared with the consumption of artificial protein diets (Cook et al. 2003; Tasei and Aupinel 2008). Also, Carroll et al. (2017) found that bees preferentially consumed freshly stored pollen ( 1 day old) over pollen that had been stored (and fermented) for a longer period, when choosing what was available in the hive.

Fermentation significantly increased diet consumption and the protein levels of bees fed on the pollen substitute diet (K and KS, 7 days). The highest protein levels were found in bees that consumed beebread, as also found by Cremonez et al. (1998), Van der Steen (2007), and Basualdo et al. (2014). We observed a reduction in the crude protein content of the fermented diets when compared with the fresh diet; this was due to protein consumption by microorganisms, which also require protein for their metabolism, using them as a source of energy and carbon (Tortora et al. 2012).

The protein percentage of the diets was quantified by bromatological analysis by the Kjeldahl method, which measures the total amount of organic and inorganic nitrogen contained in a sample; whereas the hemolymph proteins were measured by the Bradford method, which quantifies the main proteins that bind with the Coomassie blue dye, and therefore has a different method of quantification. Consequently, the amount of protein obtained in the diets is lower than expected, which would be around 25\%. According to Muck (1988) and Scherer et al. (2015), in general, the volatile nitrogen found in the silages is an indicator of the process of proteolysis by the microorganisms, in which they release protease enzymes capable of digesting proteins present in the ensiled material. A process of oxidation of amino acids thus occurs, releasing into the silo acetic acid, $\mathrm{NH}_{3}$, and $\mathrm{CO}_{2}$. The lactic acid should appear in a percentage higher than the others (acetic and butyric), which indicates better quality of the fermentation process and lower degradation of proteins. Sun et al. (2018) observed that silage preserved maize straw nutrients as compared with the unattached dry matter, reducing nutrient losses and inhibiting the growth of deteriorating organisms. When comparing an unfermented diet with any fermented food, one observes the microbial action altering the properties of the food with the liberation of the products resulting from this fermentation and consuming molecules for its metabolism (like carbon and nitrogen): the lactic acid bacteria generally need various amino acids and vitamins for growth (Pahlow et al. 2003) thus altering the nutrient content. However, the diets were able to provide enough nutrients for the bees, since there was a significant increase in the amount of hemolymph protein of the bees that consumed the fermented diets when compared with the bees that did not consume any protein food and those that did not consume fermented diet. Calculating the amount of crude protein ingested and the amount of protein (gain) that each treatment provided in hemolymph 
Table II. Protein gain in the hemolymph $(\mu \mathrm{g} / \mu \mathrm{l})$ of bees according to the consumption of each diet

\begin{tabular}{llcll}
\hline Treatment $(\mathrm{T})$ & Consumption $(\mathrm{C})$ & Hemolymph protein $\mathrm{H}(\mu \mathrm{g} / \mu \mathrm{l})$ & Ingested protein $(\mathrm{g})$ & $\begin{array}{c}\text { Gain of protein }(\mu \mathrm{g} / \mu \mathrm{l}) \\
\text { in hemolymph compared } \\
\text { with day 0 }\end{array}$ \\
\hline Day 0 & - & & - \\
$\mathrm{C}-$ & - & 17.3 & - & - \\
$\mathrm{C}+$ & 1.7 & 12.9 & - & 23.5 \\
F (fresh) & 1.7 & 40.8 & 0.45 & 3.9 \\
K7 & 2.6 & 21.2 & 0.49 & 7.91 \\
K14 & 2.4 & 29.4 & 0.45 & 4.75 \\
K28 & 2.1 & 24.0 & 0.52 & -0.56 \\
KS7 & 3.2 & 16.6 & 0.50 & 7.22 \\
KS14 & 2.5 & 30.9 & 0.68 & 7.2 \\
KS28 & 2.5 & 27.9 & 0.53 & 4.62 \\
\hline
\end{tabular}

(Table II), the diets $\mathrm{K} 7$ and KS7, in addition to the diet KS14, obtained superior performance to the others when compared with the diet fresh (f). The K7 diet obtained $0.45 \mathrm{~g}$ of crude protein ingested and a gain of $7.91 \mu \mathrm{g} / \mu \mathrm{l}$ of protein in hemolymph; the diet KS7 obtained $0.68 \mathrm{~g}$ of crude protein ingested and gain of $7.22 \mu \mathrm{g} / \mu \mathrm{l}$ in hemolymph and KS14 obtained $0.53 \mathrm{~g}$ and a gain of $7.2 \mu \mathrm{g} / \mu \mathrm{l}$ in the hemolymph compared with $0.49 \mathrm{~g}$ and $3.9 \mu \mathrm{g} / \mu \mathrm{l}$ of fresh. Therefore, all fermented diets obtained higher protein gains in the hemolymph than the fresh diet, except the diet K28 that obtained a negative gain $(-0.56 \mu \mathrm{g})$. According to Wright et al. (2017), bees regulate food intake according to the macronutrient content; thus, the higher the nutrient content contained in a food, the lower its consumption. For honey bees, the accumulation of storage proteins (vitellogenin and hexamerin) in the hemolymph of adult workers is significantly influenced by nutrition (AlmeidaDias et al. 2018). Consequently, a diet that is able to maintain proteins in the hemolymph both qualitatively and quantitatively helps guarantee the health of the bees (Bitondi and Simões 1996). Here, we demonstrated that a fermented diet provides nutrients that are used in the synthesis of these two proteins (Figure 3). Herbert Jr and Shimanuki (1978) found that pollen substitutes can efficiently substitute pollen; however, inducing the bees to consume artificial diets can be a major difficulty. Ellis and Hayes Jr (2009) and Almeida-Dias et al. (2018) found that bees consume more of a fermented diet than an unfermented diet, as it is known that a fermented food, especially when it involves organisms such as Lactobacillus, has better texture and aroma, as observed by Behera et al. (2018), thus increasing attractiveness and acceptability. It is worth noting that our proposal is not to substitute natural food but rather to provide a quality alternative to the beekeeper during periods of low supply of pollen in nature, avoiding colony decline.

In conclusion, the standardization of the fermentation process through the use of commercial lineages of microorganisms, the shortened time needed to ferment the diets, and their attractiveness and efficacy in providing amino acids necessary to produce storage proteins in bees open the possibility of large-scale production of a fermented diet and its use in commercial apiaries.

\section{ACKNOWLEDGMENTS}

The authors thank Dr. David De Jong for reviewing the manuscript. We are also thankful to the Agência Paulista de Tecnologia dos Agronegócios (APTASAA, SP), in particular, Dr. Érica Weinstein Teixeira, for providing biological material, and we thank Natucentro for providing artificial diets for bees. 


\section{AUTHORS CONTRIBUTIONS}

JP, MM, and EE: conceived this research and designed the experiments; MM, GS, and TF: design and interpretation of the data; JP, EE, and GS: experiments and analysis; JP, MM, and TF: writing and revision. All authors read and approved.

\section{FUNDING INFORMATION}

This study was financed in part by the Coordenação de Aperfeiçoamento de Pessoal de Nível Superior-Brasil (CAPES) - Finance Code 001.

Effets de l'ensilage sur la qualité des compléments protéiques pour les abeilles (Apis mellifera)

\section{Apis mellifera / fermentation / régimes artificiels / inoculants}

Auswirkung de Silovorhaltung auf die Qualität von Pollenersatzmitteln für Honigbienen (Apis mellifera)

\section{Apis mellifera / Fermentierung / künstliche Diäten / Inokulantien}

\section{REFERENCES}

Aksu, T., Baytoka, E., Bolat, D. (2004). Technical note: effects of a bacterial silage inoculant on corn silage fermentation and nutrient digestibility. Small Rumin. Res. 55, 249-252. https://doi.org/10.1016/j. smallrumres.2003.12.012

Alberoni, D.; Gaggìa, F.; Baffoni, L. and Di Gioia, D. (2016). Beneficial microorganisms for honey bees: problems and progresses. Appl. Microbiol. Biotechnol., 100(22): 9469-9482. https://doi. org/10.1007/s00253-016-7870-4

Almeida-Dias, J. M. V; Morais, M.M; Francoy, T.M; Pereira, R.M; Turcatto, A.P and De Jong, D. (2018). Fermentation of a pollen substitute diet with beebread microorganisms increases diet consumption and hemolymph protein levels of honey bees (Hymenoptera: Apidae). Sociobiology 65, (4): 760-765 ( https://doi. org/10.13102/sociobiology.v65i4.3293) Special Issue.

Anderson KE. and Ricigliano VA. (2017). Honey bee gut dysbiosis: a novel context for disease ecology. Curr Opin Insect Sci. 22, 125-132. https://doi.org/10.1016 /j.cois.2017.05.020
Anderson, K.E., Sheehan, T.H., Mott, B.M., Maes, P., Snyder, L., Schwan, M.R., Walton, A., Jones, B.M, Corby-Harris, V. (2013). Microbial ecology of the hive and pollination landscape: bacterial associates from floral nectar, the alimentary tract and stored food of honey bees (Apis mellifera). PLoS One 8 (12) e83125. https://doi.org/10.1371 /journal.pone.0083125

Anderson, K.E., Rodrigues, P.A., Mott, B.M, Maes, P., Corby-Harris, V. (2015). Ecological Succession in the Honey Bee Gut: Shift in Lactobacillus Strain Dominance During Early Adult Development. Microb. Ecol., 71 (4):1008-19. https://doi.org/10.1007 /s00248-015-0716-2

Basualdo, M.; Barragán, S.; Antúnez, K. (2014). Bee bread increases honeybee haemolymph protein and promote better survival despite of causing higher Nosema ceranae abundance in honeybees. Environ. Microbiol. Rep. 6 (4)396-400. https://doi.org/10.1111/17582229.12169

Behera, S. S., Ray, R. C., \& Zdolec, N. (2018). Lactobacillus plantarum with Functional Properties: An Approach to Increase Safety and Shelf-Life of Fermented Foods. Biomed. Res. Int., 9361614. https://doi. org/10.1155/2018/9361614

Bitondi, M.M.G., and Z.L.P. Simões. (1996). The relationship between level of pollen in the diet: vitellogenin and juvenile hormone titers in Africanized Apis mellifera workers. J. Apic. Res. 35, 27-36. https://doi.org/10.1080/00218839.1996.11100910

Bradford, M.M. (1976). A rapid and sensitive method for the quantitation of microgram quantities of protein utilizing the principle of protein-dye binding. Anal. Biochem. 72, (1-2): 248-254. https://doi. org/10.1016/0003-2697(76)90527-3

Brindza J et al. (2010). Pollen microbial colonization and food safety. Acta Chim. Slov. 3, 95-102.

Brodschneider, R., Crailsheim, K. (2010). Nutrition and health in honey bees. Apidologie 41 (3), 278-294. https://doi.org/10.1051/apido/2010012

Carroll, M.J et al.(2017).Honey bees preferentially consume freshly-stored pollen. PLoS One 12 (4): e0175933. https://doi.org/10.1371/journal. pone. 0175933

Cook, S.M; Awmack, C.S, Murray, D.A and Williams, I.H. (2003). Are honey bees' foraging preferences affected by pollen amino acid composition? Short Communication. Ecol. Entomol. 28, 622-627. https://doi. org/10.1046/j.1365-2311.2003.00548.x

Crailsheim K. (1990). The protein balance of the honey bee worker. Apidologie 21, 417-429. https://doi. org/10.1051/apido:19900504

Cremonez, T.M; De Jong, D, Bitondi, M.M.G.(1998).Quantification of hemolymph proteins as a fast testing protein diets for honey bees (Hymenoptera: Apidae), J. Econ. Entomol. 91, 1284-1289.

De Jong D. et al. (2009). Pollen substitutes increase honey bee haemolymph protein levels as much as or more than does pollen. J. Apic. Res. 48 (1), 34-37. https://doi.org/10.3896/IBRA.1.48.1.08 
DeGrandi-Hoffman G, Eckholm BJ, Huang MH. (2012). A comparison of beebread made by Africanized and European honey bees (Apis mellifera) and its effects on hemolymph protein titers. Apidologie; 44 (1) 5263. https://doi.org/10.1007/s13592-012-0154-9

DeGrandi-Hoffman, G. et al. (2018). Connecting the nutrient composition of seasonal pollens with changing nutritional needs of honey bee (Apis mellifera L.) colonies. J. Insect Physiol.,109, 114-124.https://doi. org/10.1016/j.jinsphys.2018.07.002

Ellis, A.M. and Hayes Jr, G.W. (2009). An evaluation of fresh versus fermented diets for honey bees (Apis mellifera). J. Apic. Res. 48 (3), 215-216. https://doi.org/10.3896/IBRA.1.48.3.11

Gilliam, M., Roubik, D.W., Lorenz, B.J. (1990). Microorganisms associated with pollen, honey, and brood provisions in the nest of a stingless bee, Melipona fasciata. Apidologie 21 (2), 89-97. https://doi. org/10.1051/apido:19900201

Haydak, M.H. (1963) Age of nurse bees and brood rearing. J. Apic. Res. 2 (2), 101-103. https://doi.org/10.1080 /00218839.1963.11100067

Herbert Jr, E.W. (1992) Honey bee nutrition. In 'The hive and the honeybee'. (Ed. JM Graham). Dadant and Sons: Hamilton, pp. 197-233.

Herbert Jr, E.W and Shimanuki, H. (1978). Chemical composition and nutritive value of bee-collected and beestored pollen. Apidologie 9 (1), 33-40. https://doi. org/10.1051/apido:19780103

Herbert Jr., E.W and Shimanuki, H. (1977) Brood-rearing capability of caged honeybees fed synthetic diets. J. Apic. Res. 16 (3), 150-153. https://doi.org/10.1080 /00218839.1977.11099877

Hoover, S.E.R., Higo, H.A., Winston, M.L. (2006). Worker honey bee ovary development: seasonal variation and the influence of larval and adult nutrition. J. Comp. Physiol. B.176, 55-6.https://doi.org/10.1007/s00360005-0032-0

$\mathrm{Hu} \mathrm{X}$ and Beeton, C.(2010). Detection of functional matrix metalloproteinases by zymography. J. Vis. Exp. 45, e2445.https://doi.org/10.3791/2445

Keady, T.W.J., Steen, R.W.J., Kilpatrick, D.J., Mayne, C.S. (1994). Effects of inoculant treatment on silage fermentation, digestibility and intake by growing cattle. Grass Forage Sci. 49, 284-294. https://doi. org/10.1111/j.1365-2494.1994.tb02003.x

Kristensen, N.B., Sloth, K.H., Højberg, O., Spliid, N.H., Jensen, C., Thøgersen, R. (2010). Effects of microbial inoculants on corn silage fermentation, microbial contents, aerobic stability, and milk production under field conditions. Dairy Sci. 93, 3764-3774. https://doi. org/10.3168/jds.2010-3136.

Kung, L., Ranjit, N.K. (2001). The Effect of Lactobacillus buchneri and Other Additives on the Fermentation and Aerobic Stability of Barley Silage. J. Dairy Sci. 84 (5), 1149-1155. https://doi.org/10.3168/jds.S0022-0302 (01)74575-4

Loper GM et al. (1980). Biochemistry and microbiology of bee-collected almond (Prunus dulcis) pollen and beebread. I- Fatty Acids, Sterols, Vitamins and Minerals. Apidologie, Springer Verlag.; 11 (1), 63-73. https://doi.org/10.1051/apido:19800108

Morais, M.M., Turcatto, A.P., Francoy, T.M., Gonçalves, L.S., Cappelari, F.A., De Jong, D. (2013a). Evaluation of inexpensive pollen substitute diets through quantification of haemolymph proteins. J. Apic. Res. 52 (3), 119-121. https://doi.org/10.3896/IBRA.1.52.3.01

Morais, M.M., Turcatto, A.P., Pereira, R.A., Francoy, T.M., Guidugli-Lazzarini, K.R., Gonçalves, L.S., AlmeidaDias, J.M.V., Ellis, J.D., De Jong, D. (2013b). Protein levels and colony development of Africanized and European honey bees fed natural and artificial diets. Genet. Mol. Res. 12 (4), 6915-6922. https://doi. org/10.4238/2013.December.19.10

Muck, R.E. (1988). Factors influencing silage quality and their implications for management. J. Dairy Sci.; 71 : 2992-3002.

Nicolson SW. (2011). Bee Food: The Chemistry and Nutritional Value of Nectar, Pollen and Mixtures of the Two. Afr. Zool. 46 (2): 197-204. https://doi. org/10.3377/004.046.0201

Pahlow, G.; Muck, R.E.; Driehuis, F. et al. (2003). Microbiology of ensiling. In: Buxton, D.R.; Muck, R.E.; Harrison, J.H. (Eds.) Silage science and technology. Madison: American Society of Agronomy, Crop Science Society of America, Soil Science Society of America. p. 31-93.

Paiva, J.P.L.M., Paiva, H.M., Esposito, E., Morais, M.M. (2016). On the Effects of Artificial Feeding on Bee Colony Dynamics: A Mathematical Model. PLoS One 11 (11), e0167054. https://doi.org/10.1371/journal. pone. 0167054

Peng, Y., D’Antuono, M., Manning, R. (2012). Effects of pollen and artificial diets on the hypopharyngeal glands of newly hatched bees (Apis mellifera L.). J. Apic. Res. 51 (1), 53-62. https://doi.org/10.3896/IBRA.1.51.1.07

Roulston, T.H. and Cane, J. (2000). Pollen nutritional content and digestibility for animals. Plant Syst. Evol. 222, 187-209. https://doi.org/10.1007/BF00984102

Scherer, R., Gerlach, K., Sudekun, K.H. (2015). Biogenic amines and gamma-amino butyric acid in silage: Formation, occurrence and influence on dry matter intake and ruminant production. Anim. Feed Sci. Technol., 210:1-16.

Schmidt, J.O. and Hanna, A. (2006). Chemical nature of phagostimulants in pollen attractive to honeybees. J. Insect Behav. 19, 521-532. https://doi.org/10.1007 /s10905-006-9039-y

Schröder, J.J; de Visser, W; Assinck, F.B.T; Velthof, G.L. (2013) Effects of short-term nitrogen supply from livestock manures and cover crops on silage maize production and nitrate leaching. Soil Use and Management 29 (2):151-160.

Somerville, Doug \& Rural Industries Research and Development Corporation (Australia) (2005). Fat bees skinny bees: a manual on honey bee nutrition for beekeepers: a report for the Rural Industries Research and Development Corporation. Rural Industries Research and Development Corporation, Barton. 
Sun, L. et al. (2018). Changes in microbial population and chemical composition of corn stover during field exposure and their evaluation on silage fermentation and in vitro digestibility. Asian Australas. J. Anim. Sci. https://doi.org/10.5713/ajas.18.0514

Tasei, J.N., Aupinel, P. (2008). Nutritive value of 15 single pollens and pollen mixes tested on larvae produced by bumblebee workers (Bombus terrestris, Hymenoptera: Apidae). Apidologie 39, 397-409. https://doi. org/10.1051/apido:2008017

Tortora, G. J.; Funke, B.R.; Case, C. L. (2012). Microbiology: An Introduction.10th Edition. Pearson Education, Inc., publishing as Benjamin Cummings, $937 \mathrm{p}$.

Urcan, A.C.; Criste, A.D.; Dezmirean, D.S.; Mărgăoan, R.; Caeiro, A.; Graça Campos, M. (2018). Similarity of data from bee bread with the same taxa collected in India and Romania. Molecules 23, 2491. https://doi. org/10.3390/molecules23102491

Van der Steen, J. (2007). Effect of a home-made pollen substitute on honey bee colony development. J. Apic. Res. 46, 2. https://doi.org/10.3896/IBRA.1.46.2.09.
Vasques, A., Olofsson, T. (2009). The lactic acid bacteria involved in the production of bee pollen and bee bread. Apicult. Res. Bee World 48(3): 189-195. https://doi. org/10.3896/IBRA.1.48.3.07

Venus, J., Ilder, F., Albrecht, C. (1992). New ways of selecting lactic acid bacteria for biotechnological processes. Appl. Microbiol. Biotechnol., 37 : 240-243. https://doi.org/10.1007/BF00178178

Winston, M. (2003). The Biology of the Honey Bee. Harvard University Press, $294 \mathrm{p}$.

Wright, G.A.; Nicolson, S.W; Shafir, S. (2017). Nutritional physiology and ecology of honey bees. Annu. Rev. Entomol., 63 : 327-344. https://doi.org/10.1146 /annurev-ento-020117-043423

Publisher's note Springer Nature remains neutral with regard to jurisdictional claims in published maps and institutional affiliations. 